\title{
Women's Participation in Politics and Development in West Java Province, Indonesia
}

\author{
Tuswoyo Admojo, Paisal Halim \\ Institut Ilmu Sosial dan Manajemen STIAMI, Faculty of Public Administration \\ Let. Jend. Suprapto Road, DKI Jakarta 10530, Indonesia
}

\begin{abstract}
The phenomenon of lower political participation of lower-class women in urban areas, is getting worse when the various policies adopted by the government do not side with the urban women's groups for the lower classes. The research method used in this research is a descriptive qualitative approach. This sampling technique used in studies that prioritize the purpose of research than on the nature of the population in determining the sample research. Therefore, in this study, no random samples were used, but the samples purposive samples. Primary data includes data obtained directly from respondents or informants through in-depth interviews with a final questionnaire of 40 respondents consisting of various professions, while secondary data is data obtained from documents that have been authorized or have published. Women's participation in urban village development strongly influenced by different factors, ranging from socio-economic, cultural, to lifestyle issues. Groups identified as mothers or socialite women living in luxury housing tend to be less concerned with the common interests of people, while women or mothers who live in ordinary or village house although they have a high level of concern for development issues run by sub-district was facing various problems when running the role of participation. As a result, qualitatively the role becomes less than optimal.
\end{abstract}

Keywords: Women's Participation, Politics, Development, and Public Participation

\section{Introduction}

The development of a state mainly aimed at improving the living standards of the people of the nation and the state. In practice, society is no longer the object of development, but it has become the subject of development [1]. So, the participation of the community will determine the success or failure of government programs [2]. Community involvement can take the form of a contribution of mind, energy or both [3]. But it turns out, community participation in development in Indonesia is not as we expected together

The low turnout of women in regional development is one of the major themes that always arise in discussions about the repositioning of women's roles in development and politics [4]. One aspect that always emerges in this debate is the issue of women's representation in the national and regional political structures, including the involvement of women in the process of public policy formulation in the central to perceived areas is not sufficient [5]. This issue arises when comparing it dichotomously with the existence of women in a quantitative context that averages in proportion to half the national and regional population.

In 1990, UNDP (United Nations Development Program) added a new indicator to measure the success of a country's development, if previously measured only by the growth of GDP (Growth Domestic Product) now coupled with the HDI (Human Development Index), one of which is the concept of gender equality (equality between the sexes). It said that equality between the sexes factors should always include in evaluating the success of the national development. The calculation used is the GDI (Gender Development Index), which is equality between men and women in life expectancy, education, and total income, and GEM (Gender Empowerment Measure), which measures the equality of political participation [6]. The concept of gender equality in politics by the feminist movement in Indonesia is finally able to be implemented with the emergence of affirmative action that is $30 \%$ quota for Indonesian women summarized in the Election Law No. Article 65 of 2003.

The pattern of participation needs to be supported by a high level of political awareness and supported by broad access to information, which defined as a public choice concerning aspects of development [7]. If every individual already owns it, then the community will automatically participate actively in filing the demands, be involved in providing policy input, implementing policies and evaluate the implementation of the policies that have been set together [8].

Political participation is more oriented towards influencing and positioning people's representatives in governmental institutions rather than active participation in the processes of government itself [9]. Social engagement placed as a party outside the development process in consultation or decisionmaking in all stages of the development project cycle from needs evaluation to assessment, monitoring, assessment and implementation [10]. Social participation is done to strengthen the learning process and social mobilization [11]. In other words, the primary purpose of the social process is not in the public policy itself, but the involvement of the community in the world of public policy is directed more as a vehicle for learning and social mobilization. While citizen participation emphasizes the direct involvement of citizens in decision-making in government institutions and processes [12]. Citizen participation has shifted the concept of involvement from little concern to the beneficiaries of the charity or the marginalized to a concern with various forms of citizen participation in policy-making and decision-making in the major roles affecting their lives [13]. So different from social engagement, civic participation oriented on the agenda of public policy determination.

\section{Volume 6 Issue 10, October 2017}




\section{International Journal of Science and Research (IJSR) \\ ISSN (Online): 2319-7064}

Index Copernicus Value (2015): 78.96 | Impact Factor (2015): 6.391

Women's political participation can be conventional and can be non-conventional. It is only then that formal opportunities influence women's participation, whether women given the chance to be in the political arena, meaningful social resources whether they have the ability to go into the region and the personal motivation or willingness of women to be actively involved in it [14], [15].

There is widespread government involvement in social, economic and cultural affairs. The general scope of government activity often stimulates the growth of organized demands to participate in influencing the actions of political decisions. It is a consequence of the decisions of the government in all spheres of life.

Today, more than 95 percent of the countries in the world guarantee the two most fundamental democratic rights for women: the right to vote and right to stand for elections. According to [16], the right to run for election, to become a candidate, and to vote, is based on the right to vote. However, women's rights are limited because basically only candidate men who have right to vote. The reason for the violation of human rights is the low level of women's representation in some parliaments [17].

According to [18] to achieve this level of political consciousness is not easy, to make it we need to implement the five steps of participatory strategy. Group representation of active citizens is required; appointment of local leaders to occupy official positions; giving people the possibility to choose one among several plans; consultation throughout the planning process; include community representatives on the decision-making board and community control over expenditure costs.

This condition often leads to social prejudices of gender inequality in development, reflected in the reality of representation of women physically within the legislature is very minimal, which then have the opportunity to not represent the aspirations of women in the process of public policy formulation that is gender sensitive or side with the interest's women and issues directly related to the life and rights of women [19]. These issues came to be known as softpolitics or conventional politics, which are the domain of women and can only be understood and occupied by women. These political issues are often regarded not as political issues, so they are barely included in the realm of life and the political way of thinking of men, which include issues such as the welfare of children, the protection of women's reproductive rights and so on [20]. It is in this context that the belief in women's wider involvement in politics becomes so necessary to reduce the gap between conventional politics and hard politics issues [21]. Well-founded considering that women's political attitudes are more inclined to emphasize traditional political matters than hard policy [22]. So, it is necessary a scientific study on the participation of women in politics and development.

\section{Method}

\subsection{Research Design}

The research method used in this research is a descriptive qualitative approach. [23] Suggests an illustrative method is a method of a study conducted with the primary purpose to create a picture or description of a situation objectively. Qualitative research according to [24] is said to be an analysis procedure that produces descriptive data in the form of written or oral words of people and behavior that can observe. This study according to [25] intended as an exploration and clarification of a phenomenon or social reality by describing some variables concerning the problem and the unit under study.

\subsection{Source of Information and Selection of Respondents}

In qualitative research, the researcher very closely related to contextual factors. So, the purpose of sampling, in this case, is to capture as much information from various sources and buildings. Thus, the goal is not to focus on the differences that will later be developed in generalization but to itemize the specificity that exists in a unique contextual herb. Therefore, in this study, no random samples were used, but the samples were purposive (purposive samples). This sampling technique used in researches that prioritize the purpose of research than on the nature of the population in determining the sample research. Based on knowledge of the population, the population units considered "core," taken as research specimens. That then defined as informants. Informants in this study are:

1) Village Heads in Jatirahayu, Pondok Melati, and New Jatibening Villages, Pondok Gede, Bekasi, West Java.

2) Secretary of Jatirahayu urban village, Pondok Melati and New Jatibening urban village, Pondok Gede, Bekasi, West Java.

3) Board and members of Posyandu, Youth organization, Cooperative, LMD, LPM or LKMD, PKK or LPP.

4) Head Section-head section in Jatirahayu urban village, Pondok Melati and New Jatibening, Pondok Gede, Bekasi, West Java.

In-depth interviews with closed questionnaires were 40 respondents consisting of various professions, ranging from community leaders to PKK/women's organizations in the subdistrict.

\subsection{Data Collection Procedures}

Data needed in this research is primary data and secondary data. Primary data includes data obtained directly from respondents or informants through in-depth interviews, while secondary data is data obtained from documents that have been authorized or have published. Primary and secondary data collection is done by:

\section{- Deep interview}

Interviews by proof of information or information obtained previously [26]. Interview techniques used in qualitative

\section{Volume 6 Issue 10, October 2017} www.ijsr.net 


\section{International Journal of Science and Research (IJSR) \\ ISSN (Online): 2319-7064}

Index Copernicus Value (2015): 78.96 | Impact Factor (2015): 6.391

research are in-depth interviews [27]. In-depth interviews are the process of collecting information for investigation by questioning and face-to-face manner between the interviewer and the informant or interviewee, with or without using discussion guidelines, where interviewers and informants engage in relatively long social life [28][29]. The interviewer in this study is the researcher himself and the source who will interview.

\section{- Observation}

Stated that the view includes four aspects namely a) research location; b) who will be observed or interviewed; c) any event or event felt by the actor to be the topic of interview and observation; and d) the nature of the game felt by the player in the research location [30].

\section{- Documentation}

Many facts and data stored in the material in the form of documentation. Most of the available data is in the form of letters, diaries, souvenirs, reports, artifacts, photographs and so on. The general nature of this information is infinite space and time, so it gives an opportunity to the researchers to know things that have happened in the past.

Document data collection is done to collect data sourced from archives and documents either in Bugis Village Health Center or outside of the hospital that must do with research conducted. While the documentation techniques developed by the needs of research are to collect data in the form: Profiles, Reports and other documents that support.

\section{Result and Discussion}

As regulated in Law No.23 of 2014 on regional development planning, Article 261 (1) argues that: Regional development planning uses a technocratic, participatory, political, topdown and bottom-up approach. Then in Paragraph (3), it is explained that Participatory approach as referred to in paragraph (1) implemented by involving various stakeholders. Therefore, the community as the subject of development can influence the policy of local government through its involvement in the process of making the system of the sub-districts. In this context, it will explain about the path of participation that citizens can use to engage in planning and implementation of development, then on the factors that influence participation, along with strategies that can do to streamline such participation.

\subsection{Path Participation in Decision Making Process}

Based on Law No. 23 The year 2014 Article 187 Paragraph (3) stated that: Community involvement as referred to in paragraph (1) includes: a). Compilation of local regulations and regional policies that regulate and burden the community; b). Planning, budgeting, implementation, monitoring, and evaluation of regional development; c) Management of assets and natural resources of the Region; and d). Public service delivery.

In Paragraph (4) it is explained that: Community participation as referred to in paragraph (3) shall conduct in the form of a) Public consultation; b) Discussion; c) Partnership; d) The delivery of aspirations; e) supervision; and $\mathrm{f}$. other involvement by the provisions of the legislation. Then in Paragraph (6), it is argued that: The government regulation as referred to in paragraph (5) shall at least regulate: a) the procedure of public access to information on the administration of the Regional Government; b) Institutional and mechanism of public participation in the implementation of Regional Government; c) Forms of public involvement in the management of the Regional Government; and d) support of capacity building for groups and community organizations to participate effectively in the implementation of Regional Government. Related to the explanation in the legislation, the process of community participation can be done through 3 (three) paths as follows:

\section{- Through the Institutional Path}

Public involvement in determining the development policy can do by occupying certain positions in the village, starting as Head of sub-district, Secretary of the sub-district chief and Section Heads in their respective fields, even RW, RT, subdistrict hospital, religious leaders, and Community Self-Help Institution or Agency Self-Reliance Society. By holding these positions, participation at the level of discussion or decisionmaking (legitimation participation) of the project can do more efficiently. From the data, two women occupy a prominent position in the village of Jatirahayu, Pondok Melati. In addition to the Head of sub-district a woman, there is also a woman who became the head of the RT in the subdistricts working area that includes RT and RW.

The confirmation of the respondents consisting of several professions involved in the Development Planning meeting showed that less than $15 \%$ of women in the village and nongovernmental organizations are actively voicing women's policies. Most $45 \%$ say more about general programs, and the rest only follow the joint decisions made by deliberations. Some Development Planning meeting participants who had conducted interviews and happened to the head of RT explained that some of the participants realized that the current development priorities are still on the improvement of the environment, such as water channels, village roads. There are plans to build landscaping, but still limited to the park has not talked completeness. It argued that for the neighborhood of ASI cultivated will be held, but it depends on the available budget.

In the effort to occupy these positions is not easy, the informant itself through mutations from various previous government positions. At least four stages, and through at least four new tests obtained the position. It means to place in the post of the Head of sub-district is not enough with education, but also persistence, patience and patience and achievement. But all that assess the leadership, because previously concerned also served as a Head of sub-district in one village in Pondok Gede.

It applies to anyone indistinguishable in gender. A woman who wants to occupy the position as Head of Village must first career in bureaucracy because sub-district is are work unit of government bureaucracy system. In an interview with Head of sub-district in Jatirahayu, there were explanations

\section{Volume 6 Issue 10, October 2017}




\section{International Journal of Science and Research (IJSR) \\ ISSN (Online): 2319-7064}

Index Copernicus Value (2015): 78.96 Impact Factor (2015): 6.391

related to the process, the informant then became Head of sub-district. It openly explained that the process is not only massive because it must follow the test up to four times, but it also takes patience to be promoted as Head of sub-district in Bekasi.

The involvement of women in the public sphere does not arise autonomously but influenced by the immediate environment, which performed by the husband [31]. This information appears when asked about the initial motivation of women involved entering public areas such as engaging in political parties and the like.

Although some women try to seem to run public roles, still most are only placed as a compliment. The situation of the meeting is very unfriendly to women, complete with a variety of humor of men's tastes that mostly exploit female sexuality, psychologically most make women do not like to linger in the forums [32], [33]. Because of women despite the public sector, still carrying roles that still associated with its domestic role, such as $\mathrm{MC}$, receptionist, consumption section, and so on.

\section{- Through the Decision-Making Process}

The decision process at the sub-district level is known as PreMusrenbang and Musrenbang. Through pre-Musrenbang all wishes and proposals submitted, to then be recorded and arranged in the program to be discussed in Musrenbang. Through Musrenbang, which involves PKK, Posyandu, principals, BKM and MFIs, and RW / RT, as well as community representatives such as clerics, are discussed. In the deliberations, various proposals were proposed, including the improvement of the environmental roads that became a community consensus. Where some of the suggestions from women are more about things that concern them like breastfeeding moms in the office, garden improvements and toilets deserve women. In the meeting, women's involvement represented organizations such as PKK and Posyandu, even women's RT. In the explanation of the New Head of New Jatibening, Musrenbang results were then incorporated into e-planning at the sub-district level and forwarded to the city administration to subsequently designated as a sub-district program.

In the explanation of one of the heads of women RTs who had been interviewed, explaining that in these meetings there is almost no discrimination between men and females, although in numbers it is more men. Meanwhile, about the involvement of women in the preparation of programs related to public services, it is still limited to current matters, such as issues that become the work field of PKK and mothers in Posyandu. For other areas, there are still many that come (proposed) by men. But because of the woman's Head of subdistrict, all proposals must go through or to the knowledge of the village head, so it is not possible to be left if it is against the interests of women.

\subsection{Factors Affecting Women's Participation}

In the above explanation, it appears that there is the polarization of women in participating in the public sphere. Polarization occurs in two major groups, i.e., $60 \%$ of mothers living in luxury housing complex a tend to be more selfinterested, and less concerned with the environment, including about urban village programs, and parents who live in ordinary housing that amounted to between $40 \%$ of the population who tend to be more concerned and willing to participate in social environmental activities as well as urban village programs. In amounts ranging from $40 \%$, some obstacles often hinder the process of participation includes: First, although institutional access has been more open, either through the Posyandu, PKK activities and its involvement in Musrenbang and $\mathrm{P} 3 \mathrm{BK}$, but, in the process both quantitatively and qualitatively women's participation is still relatively small. It means that the number of women's involvement is still minimal, while the influence is still minimal. From interviews with Head of sub-district New Jatibening, the participation of women in Musrenbang is relatively small, $15 \%$ and they represent women's social organizations or women's shelter institutions, such as PKK and POSYANDU, some are from RT, but from RW none. Community leaders and clerics are also mostly men. In the Head of sub-district opinion, the small role of women related to the social reality that is divided. Indeed, for women living in luxury housing, their education level is relatively high, but for women living in ordinary housing and willing to engage in social issues, it is relatively small. It means that constraints that inhibit the participation of quantitative and qualitative one of which is the level of education of women who are willing to be active in the stewardship at the sub-district level. In other words, poor participation qualitatively related to the ability or personal capacity of the mothers who live in the non-residential areas. Most of them do not have universities, even most of junior high school graduates or high school dropouts.

Second, the lack of participation is also related to the conservative view of women who tend to be less open to the public sphere. As it is known that this traditional view develops in the marginal areas that are less touched by modernization. The concept of women as "friends behind," still prevails among the Betawi people periphery, consequently for the affairs in the public sphere is still dominated by men. In the explanation Head of sub-district, New Jatibening stated that the burden of the family, along with conservative views are increasingly charging women to be involved in social affairs.

Fourth, the equally important factor is the issue of political access for women who are economically and educatively relatively small. Although access to power sources is increasingly open, the socio-economic burden that affects these lower-class women has a profound effect on women's willingness of this lower class to participate in the political decision-making process. Also, the socio-economic conditions themselves have reduced the ability of women to engage in public affairs.

From the results of the final interviews conducted on the respondents, shows that economic problems occupy the highest level, about $50 \%$, followed by education, $30 \%$ and $10 \%$ of social issues or views of life that are still a conservative influence on the participation of women in the sub-district. Although for the economic aspect, not solely the

\section{Volume 6 Issue 10, October 2017




\section{International Journal of Science and Research (IJSR) \\ ISSN (Online): 2319-7064}

Index Copernicus Value (2015): 78.96 | Impact Factor (2015): 6.391

problem of poverty but rather because of the business of earning a living. Is means because the firm of making a living, so it can not actively participate in social affairs.

\subsection{Strategies for Increasing Women's Participation}

Under Law No.23 of 2014 Article 354 Paragraph (1) stated that: In the implementation of Regional Government, Local Government encourages community involvement. In Paragraph (2) it is argued that: In encouraging community involvement as referred to in paragraph (1), the Regional Government: a. to convey information about the implementation of Regional Government to the public; $b$. Encouraging community groups and organizations to take an active role in the implementation of the Regional Government through community capacity building support; c) Developing institutional and decision-making mechanisms that enable community groups and organizations to engage effectively. About the provisions of the legislation it can be found that the two sub-districts have made the following efforts:

\section{- Encouraging women to occupy public office in the Sub-district}

Open positions in urban villages cannot be contested through election contestation, since government officials in the subdistrict, from the Village Head to the Head of the Affairs, are part of the Local Government Work Unit (SKPD), so they are automatically civil servants. Therefore, these positions can only be fought through the Regency / City, or through competition within the internal bureaucracy. In the internal administration game, there is only one way to do that is through increased professionalism or individual performance improvement. It means that for women to be able to occupy a public office at the urban village level, there is no other way except a woman to increase its competitiveness. Although the advantages in ability are often not enough for women because the formal requirements that are intended to occupy important positions in the bureaucracy must pass in ways that are often less favorable to women. As a result, the existing public office formation becomes an opportunity to be occupied by men.

\section{- Encourage women to become social activists}

Political ability is often not correlative with the level of political understanding, the political ability of a person is more determined or influenced by practical experience in the field. Therefore, when a person is not a career in the bureaucratic path, there is one way that is actively involved in becoming a social activist in various social organizations that exist. With the involvement of a person in a social organization, it is not only the experience to be gained, but also the opportunity to fight for the aspirations of the community to be more open. Through Deliberation of urban village development plans, the struggle of women's interests can do.

Assuming that women are more likely to be carriers of gender-responsive development mandates, social institutions, such as LKMD, NGOs, Posyandu, etc. can be the main channel in the struggle for women's interests. Indeed, for certain posts such as Chairman of Youth organization,
Chairman of the Security, still very gender biased, so it will be difficult for women to occupy these posts. But for the outposts, even those who are often involved in Deliberation of urban village development plans, such as PKK, Posyandu, PAUD (Early Childhood Education) managers can be controlled by women.

\section{- Perform a cultural transformation}

About group leadership, which developed in the regions of Indonesia, [34] describes the role of priyayi as a cultural leader imitated by many peasants, and the position of kyai as the leader of santri, and the shaman as a place to ask for abangan. Although [35] saw primordial ties still echoed as the foundation for the creation of political unions. [36] understands that traditional patronage always preserved.

Nevertheless, as Indonesian society is managed from top to bottom, and from center to region, the wisdom and decisions made by superiors are important factors in everyday life. It means that the vertical structure preserved by the centralist policies of the government, where formal and informal leaders play a significant role in it. In building the state relations and social forces that developed in society, the military developed the concept of a bureaucratic authoritarian state corporatism (corporatism state). A strategy for controlling civil society through the mechanisms of corporatization.

By following it, the subordination of women under the man is often not realized itself and withdraws it in such symbolic violence. Usually, the symbolic principles of language, a way of thinking, a way of working and the way of acting are known and accepted by the master or the master.

\section{- Community economic empowerment}

The problem of urban society is the existence of a paradox between elites versus non-elite groups. The elite lives in luxury housing, while non-elite groups live in the ordinary or even shabby house. The dwelling itself reflects socioeconomic status, an identity so that the paradox associated with the residence reflects socio-economic disparity. The implications of these social realities make urban structuring policies, as well as their empowerment more focused on socio-economic groups lagging those living in the elite housing.

In such a reality, as stated by Head of sub-district New Jatibening explained that to improve the living standards of people living in public housing areas, urban villages try to encourage MSMEs by providing training and facilitating to improve their capital. The increase of MSMEs becomes significant to absorb labor, especially homemakers or women in the environment where UMKM.

In the New Jatibening Village explanation that the focus of urban village attention is not on the mothers or women in luxury housing which amounts to approximately $60 \%$ of the population, but more to the mothers or women in the nonresidential involved area or occupies the village houses, and many of the original residents of New Jatibening village. The primary consideration is the mothers or women who live in luxury housing, or that is said by the urban village of Head of

\section{Volume 6 Issue 10, October 2017




\section{International Journal of Science and Research (IJSR) \\ ISSN (Online): 2319-7064}

Index Copernicus Value (2015): 78.96 | Impact Factor (2015): 6.391

sub-district as socialite, less interested in active social activities held by the community, in addition, there is no need for a helping hand of the government because basically, they have been independent, able to organize his own life or future.

\subsection{The Village Head Ownership}

There are some questions related to the existence of subdistrict headed by a woman. Starting from the attitude of society to the leadership of women, obstacles/challenges faced by a woman headman to a public policy put forward by women headman.

\section{- Public Attitudes toward the Women's Village Head}

Both the results of interviews with closed questionnaires and open interviews obtained an explanation that most people do not reject or question the existence of women headman. Only a small minority still doubt the existence of female heads of households, especially from conservatives, 5\%. In an exclusive interview with the New Jatibening urban village, it pointed out that in the beginning there were, rejection voices, but with an ongoing approach to society, they were increasingly aware that the women's headman seemed to care more about the interests of mothers, communities with the greatest degree of participation in community matters, such as maternal and child health, sanitation, Posyandu activities, PKK, etc.

Some also assume that women heads of the village are less flexible in performing their duties, especially when there is a gathering of citizens at night. The urban sub-district himself acknowledges the notion that female headman is less flexible by stating that: "There are few issues related to their existence as women when attending religious events, such as meetings in religious forums that avoid the clergy that they are men. For social events conducted at night usually represented to the secretary of the village. "The rest no problem, the relationship between the Head of sub-district and the community was getting closer. Recognized also by one of the government staff who witnessed every meeting in Posyandu, PKK, and meetings involving women, it seems that the women headman is closer to the community because it better understands the problems faced by women.

In an interview with one of the sub-district staff who had been working in the village, the Head of sub-district of ordinary women were more disciplined in administration, and more concerned with matters of administrative or office needs. Meanwhile, about work program planning, women's urban village heads are more inspirational to accommodate citizens' complaints both in forums and Musrenbang when they go to the field.

Although often in the public view of women is considered very soft or soft against subordinates, but in solving the problem is not the case. One example of the New Jatibening urban village took a firm stand against the irregularities committed against one of his staff who reportedly residents had collected a certain amount of money that was taking care of business domicile.
From the results of a final interview, it found that more than $80 \%$ of the people do not reject the women headman, and do not consider that the female headman is less flexible. Approximately $79 \%$ stated that women Head of sub-district seemed more concerned with the community, paying more attention to matters of interest to the community

\section{- Obstacles of Women's Village Head}

The internal barriers come from the woman's personality and the work environment in which the Head of sub-district located. While external obstacles come from outside the community, where the sub-district located.

Internal barriers, As the Head of sub-district, acknowledged that in carrying out the task there has never been a problem. Few problems arise related to meetings with scholars or religious leaders who cannot make themselves in the lead position. During the meeting, a woman headman was forced to sit on the edge, making it impossible to utilize the forums as a means of socializing the policy. The position of the Head of sub-district in the forum is no more just a follower, so it is impossible to give his speech to socialize the policy which is necessary for the effort to overcome the cultural problems that can hamper the role of women.

Still associated with internal barriers, there are also people who think that women are less able to be close to the male staff, so it will certainly affect the communication or work process in the sub-district itself.

External Barriers, in a final interview, one of the heads of women RT acknowledged that there are still cultural barriers associated with religious views that assume that female leaders are a substitute alternative when there are no longer male leaders. Although the numbers are relatively few and not decisive because the Head of sub-district is in fact not elected through the election of the Head of sub-district, in the rural areas the influence of conservative thought is still huge impact, especially when the village head is directly elected.

Related to these internal and external barriers, it does not significantly affect the leadership of women leaders. It can see when the case of extortion that happened to a small shop owner in New Jatibening sub-district by village person, immediately decided to be dismissed. In further explanation from the New Jatibening urban village, it stated that when the early arrival in this village, there are various acts of urban communities that disturb the residents, especially those related to illegal fees by municipal village officials. After further investigation, there are indications that such action is a legacy of the old tradition that must overcome. Therefore, the Head of sub-district immediately takes action against the village person who is still trying to do the action by proposing to transfer to another sub-district.

- Women's Village Head and Gender Responsive Policy The issue of gender-responsive policy will turn on two things. Firstly, does a woman headman have sufficient knowledge of gender-sensitive policy? Second, is the public demand and budget needed to encourage the emergence of gender-sensitive policy?

\section{Volume 6 Issue 10, October 2017}




\section{International Journal of Science and Research (IJSR) \\ ISSN (Online): 2319-7064}

Index Copernicus Value (2015): 78.96 | Impact Factor (2015): 6.391

A women headman argued that the issue was not on the sex knowledge that a female leader possessed, but on the demands of society and the available budget. The community prioritizes programs that have broad effects or impact on the problems faced itself, such as education, health, environmental improvement in the form of road improvements, sanitation, health center. Meanwhile, to support gender-oriented programs, there is a lack of budget or limited budget.

It means that if this is the case, then only in certain areas, in the sense that the community's physical development standard has reached which then wants/wants an improvement towards gender-responsive policy. Genderresponsive systems are thus a follow-up system after minimum development plans achieved. For example, people who still consider it necessary to build a road or a meeting hall will prioritize the development. Only then after the development can meet can be continued with genderresponsive development. As in the Village Head's explanation that the construction of shelters for abandoned children or ASI chambers in urban villages is essential but since it requires land and costs, temporarily postponed.

About the issue, Head of sub-district New Jatibening explained that to support aspirated or accommodative activities to the interests of women, especially the mothers of the underprivileged is to encourage the activities of MSMEs in this village to increase their business, thus thereby will absorb the forces of the business environment. In further explanation, in this village there are two relatively advanced SMEs, namely the Business of Kerupuk Kulit and Chocolate Enterprises in addition to functioning to absorb labor, especially from among mothers can also be attempted to increase revenue for the region.

The low level of women's participation in regional development as illustrated in previous explanations at least caused by several factors, among which are cultural factors, which are related to the traditional tradition constructs in society [33]. Women's perceptions are generally about the nature of political activity identical to those of meetings at night day, tight competition and tend to dirty and justifies any means, paradigm lose-win in politics, and others, are considered contrary to the values prevailing in society [37], [38].

Moreover, coupled with the fact that in reality, the role of women is not only a domestic role because in many cases women become partners for the husband in helping the family economy [39]. The women's subordinate position in the family structure seen from the obligation of the wife to be submissive and limited as a complementary husband's office, or adherence to the provisions of the man for his public role.

\section{Conclusion}

After going through the research through in-depth interviews with municipal village officials as well as structured interviews of community members in various professional backgrounds, the following conclusions can draw:

1) Participation of women in development in the districts can do in different ways and rides. Through the institutions structurally responsible for serving the community, starting from the most basic level such as RT, $\mathrm{RW}$, up to the position of Head of the sub-district or LPM as well as the individual district's Board for the Jakarta area. In the meantime, participation can provide input into decision-making processes such as the Development Planning Council, or propose real programs through P3PK, or even control or become a partner of the subdistricts administration when carrying out policies to serve the community.

2) Women's participation in urban village development strongly influenced by various factors, ranging from socio-economic, cultural, to lifestyle issues. Groups identified as mothers or socialite women living in luxury housing tend to be less concerned with the common interests of people, while women or mothers who live in ordinary or village house although they have a high level of concern for development issues run by districts was facing various problems when running the role of participation. As a result, qualitatively the role becomes less than optimal.

3) Faced with various obstacles that can reduce the quality of participation role in urban village development, Head of the sub-district plays a role to perform strategic steps, ranging from steps to overcome economic obstacles by supporting the logging of SMEs in the region up to the cultivation of religious values in order awareness to participate can be developed.

\section{References}

[1] S. Batliwala and D. Dhanraj, "Gender myths that instrumentalise women: a view from the Indian frontline," ids Bull., vol. 35, no. 4, pp. 11-18, 2004.

[2] A. Cornwall, E. Harrison, and A. Whitehead, "Gender myths and feminist fables: The struggle for interpretive power in gender and development," Dev. Change, vol. 38, no. 1, pp. 1-20, 2007.

[3] M. Shaw, "Civil society and global politics: beyond a social movements approach," Millennium, vol. 23, no. 3, pp. 647-667, 1994.

[4] J. Ballington and E. Carrio, Women in Parliament: Beyond Numbers, A Revised. SE -103 34 Stockholm, Sweden: International IDEA, 2005.

[5] D. Dahlerup, Women, quotas and politics. Routledge, 2013.

[6] F. Noorbakhsh, "A modified human development index," World Dev., vol. 26, no. 3, pp. 517-528, 1998.

[7] R. J. Dalton, "Citizenship norms and the expansion of political participation," Polit. Stud., vol. 56, no. 1, pp. 76-98, 2008.

[8] D. S. Van Meter and C. E. Van Horn, "The policy implementation process: A conceptual framework," Adm. Soc., vol. 6, no. 4, pp. 445-488, 1975.

[9] M. Caul, "Women's Representation In Parliament: The Role Of Political Parties," Party Polit., vol. 5, no. 1, pp. 79-98, 1999.

[10] L. J. Diamond, "Toward democratic consolidation," J. Democr., vol. 5, no. 3, pp. 4-17, 1994.

[11]B. Cooke and U. Kothari, Participation: The new 


\section{International Journal of Science and Research (IJSR) \\ ISSN (Online): 2319-7064}

Index Copernicus Value (2015): 78.96 | Impact Factor (2015): 6.391

tyranny? Zed books, 2001

[12] R. Bouwen and T. Taillieu, "Multi-party collaboration as social learning for interdependence: Developing relational knowing for sustainable natural resource management," J. Community Appl. Soc. Psychol., vol. 14, no. 3, pp. 137-153, 2004.

[13] M. Barnes, J. Newman, and H. C. Sullivan, Power, participation and political renewal: Case studies in public participation. Policy Press, 2007.

[14] D. Stolle and M. Hooghe, "Shifting inequalities: Patterns of exclusion and inclusion in emerging forms of political participation," Eur. Soc., vol. 13, no. 1, pp. 119-142, 2011.

[15] P. Paxton, M. M. Hughes, and M. A. Painter, "Growth in women's political representation: A longitudinal exploration of democracy, electoral system and gender quotas," Eur. J. Polit. Res., vol. 49, no. 1, pp. 25-52, 2010.

[16] A. Keyssar, The right to vote: The contested history of democracy in the United States. Basic Books, 2009.

[17] W. Rule and J. F. Zimmerman, Electoral systems in comparative perspective: Their impact on women and minorities, no. 338. Greenwood Publishing Group, 1994.

[18] B. White, R. Little, and M. Smith, "Issues in world politics," Issues world Polit., pp. 1-23, 1997.

[19] M. M. Diaz, Representing women?: female legislators in West European parliaments. ECPR press, 2005.

[20]G. Waylen, "Women and democratization conceptualizing gender relations in transition politics," World Polit., vol. 46, no. 3, pp. 327-354, 1994.

[21]C. Pateman, The disorder of women: Democracy, feminism, and political theory. Stanford University Press, 1989.

[22]S. M. Okin, Women in western political thought. Princeton University Press, 2013.

[23] Y. K. Singh, Fundamental Research Methodology and Statistics. New Delhi, India: New Age International (P) Ltd., Publishers, 2006.

[24] S. J. Taylor, R. Bogdan, and M. DeVault, Introduction to qualitative research methods: A guidebook and resource. John Wiley \& Sons, 2015.

[25]I. Dey, Qualitative data analysis: A user-friendly guide for social scientists. London: Routledge, Taylor \& Francis Group, 2005.

[26]B. Gillham, Research Interviewing: The range of techniques: A practical guide. McGraw-Hill Education (UK), 2005.

[27] N. Britten, "Qualitative research: qualitative interviews in medical research," Br. Med. J., vol. 311, no. 6999, pp. 251-253, 1995.

[28]C. R. Kothari, Research methodology: Methods and techniques. New Age International, 2004.

[29] K. F. Punch, Introduction to social research: Quantitative and qualitative approaches. Thousand Oaks, California: SAGE Publications, Inc., 2013.

[30] J. W. Creswell, Research Design: Qualitative, Quantitative, and Mixed Method Approaches, 4th ed. Thousand Oaks, California: SAGE Publications, Inc., 2014.

[31]S. Welch, "Women as Political Animals? A Test of Some Explanations for Male-Female Political Participation Differences," Am. J. Pol. Sci., vol. 21, no.
4, pp. 711-730, 1977.

[32] M. Hooghe and D. Stolle, "Good Girls Go to the Polling Booth, Bad Boys Go Everywhere: Gender Differences in Anticipated Political Participation Among American Fourteen-Year-Olds," Women Polit., vol. 26, no. 3, pp. 1-24, 2004.

[33]L. Kenworthy, "in Political Gender Inequality Representation: A Worldwide Comparative Analysis," vol. 78, no. 1, pp. 235-268, 2013.

[34] C. Geertz, The religion of Java. University of Chicago Press, 1976.

[35]C. Geertz, "The Integrative Revolution: Primordial Sentiments and Civil Politics in the New States," Old Soc. New States, 1963.

[36] H. Feith and L. Castles, Indonesian political thinking 1945-1965. Equinox Pub, 2007.

[37] D. Hirschmann, "Women and Political Participation in Africa: Broadening the Scope of Research," World Dev., vol. 19, no. 12, pp. 1679-1694, 1991.

[38] U. N. S. Council and P. J. Chirac, "Politics in the Supermarket: Political Consumerism," vol. 26, no. 3, pp. 245-269, 2005.

[39] United Nations, "Women's Political Participation: Issues and Challenges." 2005.

\section{Abbreviations / Acronyms}

$\begin{array}{cl}\text { ASI } & \text { Breast milk } \\ \text { BKM } & \text { Community Self-Help Agency } \\ \text { LKMD } & \text { Village Community Resilience Institution } \\ \text { LMD } & \text { Village Deliberation Institution } \\ \text { LPM } & \text { Community Empowerment Institute } \\ \text { LPP } & \text { Institute for Women's Empowerment } \\ \text { MFI } & \text { Micro Finance Institution } \\ \text { Musrenbang } & \text { Deliberation of Development Plan } \\ \text { P3BK } & \text { Community Based Participatory Development } \\ & \text { Program. } \\ \text { PAUD } & \text { Early Childhood Education } \\ \text { PKK } & \text { Family Welfare Development / Women } \\ \text { Empowerment Institution } \\ \text { Posyandu } & \text { Integrated Service Post } \\ \text { RT } & \text { Neighborhood Association is the division of } \\ & \text { territory in Indonesia under Citizens Association. } \\ \text { RW } & \text { Citizens Association is the division of territory } \\ & \text { in Indonesia, under sub-district. } \\ \text { UMKM } & \text { Micro Small and Medium Enterprises. }\end{array}$

